\title{
Katı Atık Yükleme ve Taşıma Amaçlı Çok Fonksiyonlu Modüler Römorklu Araç Tasarımı
}

\author{
Osman UZUN ${ }^{1}$, Ramazan KAYACAN ${ }^{*}$ [C
}

1,2Süleyman Demirel Üniversitesi, Mühendislik Fakültesi, Makine Mühendisliği Bölümü, 32260, Isparta, Türkiye

(Alınış / Received: 21.12.2018, Kabul / Accepted: 16.10.2019, Online Yayınlanma/ Published Online: 30.12.2019)

\section{Anahtar Kelimeler}

Katı atık,

Taşıma aracı,

Küçük ve orta ölçekli

besihane,

Çapa makinası,

Modüler römork,

Konveyör bant
Özet: Günümüzde katı atıkların yüklenmesi ve taşınması için geliştirilen sistemler küçük ve orta ölçekli işlerle uğraşan çiftçilere cevap verememektedir. Bu nedenle küçük ve orta ölçekli besihaneleri olan çiftçiler temizlik için insan gücü ile katı atıkları çıkarma yoluna gitmektedir. Fakat bu temizlik, zorluğundan dolayı, her gün yapılamadığı için hayvanlarda göğüs ve tırnak iltihabı oluşabilmekte, ayrıca temizlik yapan kişilerde bel fitı̆̆ gibi hastalıklara yol açabilmektedir. Bu çalıșmada çiftçilerin özellikle küçük ve orta ölçekli besihaneler başta olmak üzere muhtelif alanlardaki çeșitli katı atıkları toplayabilmeleri, taşıyabilmeleri ve istenilen alana boşaltabilmeleri için römork kısmı küçültülüp büyültülebilen, kürüme ünitesi ile kürüme ve bantlı konveyör ile römorka yükleme işlemi yapabilen, hidrolik gücünü çapa makinasından alan araç tasarlanmış ve prototipi imal edilmiștir. Aracın tasarımında Prof. Stuard Pugh tarafından geliştirilen ve Toplam Tasarım adı verilen tasarım metodu kullanılmıştır. Tasarlanan araç, hafif ve ağır katı atıkla 150-250 $\mathrm{m}^{2}$ alanda test edilmiștir. Aracın uygulama alanı, toplama ve boşaltma süreleri göz önünde bulundurulduğunda $250 \mathrm{~m}^{2}$ 'yi geçmeyen küçük ve orta ölçekli besihanelerde kullanılabileceği sonucuna varılmıştır.

\section{Design and Production of Solid Waste Loading and Carrying Vehicle with Modular Trailer}

\section{Keywords}

Solid waste,

Transportation vehicle,

Small and medium sized barns,

Hoe machine,

Modular trailer,

Conveyor belt

\begin{abstract}
Nowadays, the systems developed for the loading and transportation of solid wastes are unable to respond to farmers engaged in small and medium scale works. Therefore, farmers having small and medium sized barns prefer to remove the solid wastes by using manpower for cleaning. However, due to the difficulty of such a cleaning, it could not be performed every day, and this causes breast and nail inflammation in animals and may also cause diseases such as herniated disc in people. In this thesis, modular device that can be used with a hoeing machine was designed and prototyped to collect, transport and discharge various solid wastes, especially in the small and medium sized barns. The modular device is composed of a trailer that its capacity be decreased or increased, a shoveling unit and a loading unit with a belt conveyor and it receives the hydraulic power it needs from the hoeing machine. Pugh's total design method developed by Prof. Stuard Pugh was used to design the device. The modular vehicle was tested with light and heavy solid wastes in areas from $150 \mathrm{~m}^{2}$ to $250 \mathrm{~m}^{2}$. From the test results, it was concluded that the modular device can be used effectively in small and medium sized barns not exceeding $250 \mathrm{~m}^{2}$.
\end{abstract}

\section{Giriş}

Günümüzde besihanelerde olușan katı atıkların toplanması, yüklenmesi ve tașınması için geliștirilmiș birçok sistem bulunmaktadır. Bu sistemler genellikle büyük ölçekli besihanelerde kullanılmakta, küçük ve nispeten küçük alanlı orta ölçekli besihanelerin çoğunda alanın küçüklüğü, maliyet gibi nedenlerle kullanılamamaktadır.

Büyük ölçekli besihanelerde temizleme işlemi genellikle besihane içerisine yerleștirilen gübre slyırıcı sistemiyle yapılmakta ve katı atıklar toplama havuzlarında depolanmaktadır (Şekil 1). 


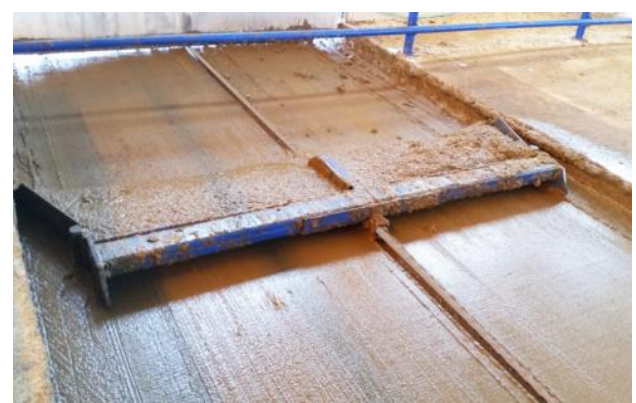

Şekil 1. Gübre sıyırıcı [1]

Gübre sıyırıcının dışında traktöre bağlanan kürüme küreği de (Şekil 2) büyük ölçekli besihanelerde katı atıkların toplanması için kullanılmaktadır.

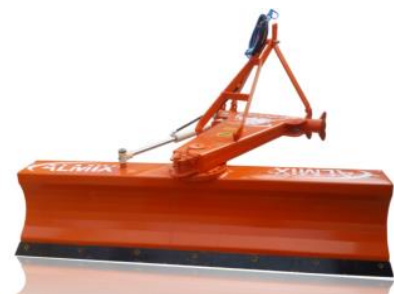

Şekil 2. Traktör kürüme küreği [1]

Toplanan katı atıklar traktöre takılan kepçe (Şekil 3) yardımıyla başka bir alana taşınmak üzere yüklenmektedir.

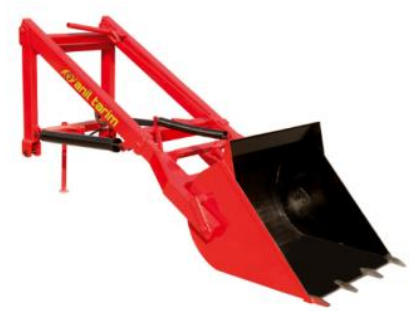

Şekil 3. Traktör kepçesi [2]

Küçük ve nispeten küçük alanlı orta ölçekli besihanelerde katı atıkları insan gücü ile çıkarma ve yükleme yoluna gidilmektedir. Katı atıkları toplamak için genellikle gelberi denilen el aleti (Şekil 4) ya da çapa makinasına takılan kürüme küreği kullanılmakta (Şekil 5) ve kürek yardımıyla başka bir alana taşınmak üzere yüklenmektedir.

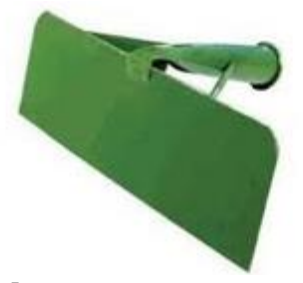

Şekil 4. Gelberi [1]

Günümüzde besicilikle uğraşan özellikle küçük ve nispeten küçük alanlı orta ölçekli işletme temizlik için insan gücü kullandığından besihanelerini her gün temizleyememektedir. Her gün temizlenemeyen besihaneler hem insanlar hem de hayvanlarda çeşitli hastalıklara neden olabilmekte, bu da işletme için önemli giderler arasında yer almaktadır. Örneğin;
Mastitis (meme iltihabı) adı verilen bir hastalık hayvanların bulunduğu çevrenin durumuna göre ortaya çlkabilmektedir. Mastitis hastalı̆̆ı hayvanların bulunduğu ortam günlük olarak temizlenmiyorsa, o ortamda bulunan mikropların meme kanalından girip meme dokusu içinde yayılması ile oluşur. Yapılan araştırmalarda ayrıca hayvanların bulunduğu ortamın düzenli olarak temizlenmemesine bağlı olarak insanların da sığır tüberkülozu hastalığına yakalanabildikleri tespit edilmiştir [3].

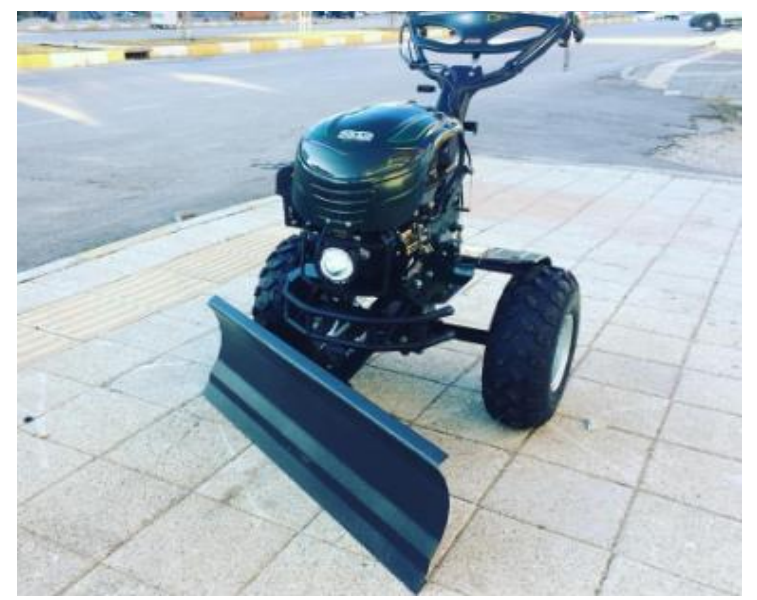

Şekil 5. Çapa makinası kürüme küreği [1]

Ayrıca ağır yük kaldırma ve taşımaya bağlı olarak insanlarda bel ağrısı meydana gelir. Örneğin; kronik hastalıklar içinde bel ağrısı, en çok karşılaş̧ılan, kişinin günlük aktivitelerini kısıtlayan ve iş gücü kaybına neden olan durumlardan biridir. Bel ağrısı; kişinin iş gücünde azalma, tanı ve tedavi maliyetleri nedeniyle, ekonomik açıdan önemli sorun teşkil eder. Yapılan araştırmalarda bel ağrısına sebep olan faktörler en çok yaş ve ağır yük kaldırma, sık öne eğilme, çekme itme, rotasyonel hareketler, postürel deformiteler, kas gücünde zayıflık, immobilizasyon, sigara ve psikolojik faktörler olarak belirlenmiştir [4].

Ticari ürünler arasında traktörle kullanılan ekipmanların yük taşıma veya yükleme kapasitesi avantaj olarak gözükse de çalışma alanının sınırlı olması, katı atık yükleme ve taşıma için ayrı ekipmanlara ihtiyaç duyulması dezavantajdır. Gübre sıyırıcı sistemi özellikle büyük besihaneler için kullanılmaktadır ve sınırlı bir alanda çalışması dezavantajdır. Çapa makinasıyla kullanılan kürüme küreği hareket kolaylı̆̆ı ve makinanın boyutlarının küçük olmasından dolayı geniş bir kullanım alanı sağlamakta, ayrıca yükleme ve taşıma işlemleri birlikte yapılmaktadır (Tablo 1).

$\mathrm{Bu}$ çalışma kapsamında tarımsal amaçla yaygın olarak kullanılan çapa makinasına eklenerek kullanılabilecek modüler römorklu katı atık toplama aracı tasarımı ve imalatı yapılmıştır. Tasarlanan araçla çiftçilerin özellikle küçük ve orta ölçekli besihanelerde ve muhtelif arazilerdeki çeşitli katı atıkları toplaması, yüklemesi, taşıması ve istenilen alana boșaltması hedeflenmektedir. Tasarlanan 
aracın küçük ve nispeten küçük alanlı orta ölçekli besihanelerde insan gücü kullanımından kaynaklı hastalıkları önlemede, iș gücü ve zaman kayıplarını en aza indirmede önemli katkısı olacağı ve benzer amaçlı daha kapsamlı ve daha verimli yeni araçların tasarımına yol açacağı düşünülmektedir.

Tablo 1. Ticari katı atık kürüme sistemlerinin karşılaștırılması

\begin{tabular}{ccccc}
\hline & $\begin{array}{c}\text { Gübre } \\
\text { Siyırıcı } \\
\text { Sistem }\end{array}$ & $\begin{array}{c}\text { Traktör } \\
\text { Kürüme } \\
\text { Küreği }\end{array}$ & $\begin{array}{c}\text { Traktör } \\
\text { Kepçesi }\end{array}$ & $\begin{array}{c}\text { Çapa Makinası } \\
\text { Kürme Küreği }\end{array}$ \\
\hline Çalışma Hızı & $1 \mathrm{~m} / \mathrm{sn}$ & $5 \mathrm{~m} / \mathrm{sn}$ & $3 \mathrm{~m} / \mathrm{sn}$ & $3 \mathrm{~m} / \mathrm{sn}$ \\
Ağırlık & $250 \mathrm{~kg}$ & $200 \mathrm{~kg}$ & $225 \mathrm{~kg}$ & $25 \mathrm{~kg}$ \\
Güç Kaynağı & $20 \mathrm{BG}$ & $45 \mathrm{BG}$ & $45 \mathrm{BG}$ & $15 \mathrm{BG}$ \\
Yük & 400 & 300 & 250 & (Min.) \\
Kapasitesi & $\mathrm{kg} / \mathrm{dak}$ & $\mathrm{kg} / \mathrm{dak}$ & $\mathrm{kg} / \mathrm{dak}$ & $65 \mathrm{~kg} / \mathrm{dak}$ \\
Çalıșma Alanı & $1.5 \mathrm{~m}$ & $2.5 \mathrm{~m}$ & $2.5 \mathrm{~m}$ & $1 \mathrm{~m}$ \\
Genişliği & (Min.) & (Min.) & (Min.) & (Min.) \\
\hline
\end{tabular}

Çapa makinası tarım işlerinde kullanılan bir arazi aracıdır. Araca farklı ekipmanlar takılarak toprağın çapalanması, ot biçilmesi, tohum ekilmesi, ağaçların ilaçlanması, römork takılıp yük taşınması gibi farklı amaçlar için kullanılabilmektedir. Yapılan literatür araştırmasında çapa makinası ile çalışan katı atık toplama aracı ile ilgili bir çalıșmaya rastlanmamakla birlikte farklı amaçlarla kullanılan ve benzer çalışma prensibine sahip makinalar bulunmaktadır. Bunlara örnek olarak asfalt kazıma makinası, balya yükleme makinası ve taş toplama makinası verilebilir.

Asfalt kazıma makinası yerden kazınan asfaltı konveyör bant yardımıyla taşıyıcı kamyona aktarmak için kullanılmaktadır (Şekil 6).

Balya toplama makinası traktöre bağlanmakta ve yerdeki balyaları taşıyıcı zincirlerle traktör römorkuna aktarmak için kullanılmaktadır (Şekil 7).

Taş toplama makinası traktöre bağlanmakta ve taşlı arazilerdeki taşları toplayarak uygun alanlara boşaltmak için kullanılmaktadır (Şekil 8).

Asfalt kazıma, balya toplama ve taş toplama makinalarının teknik özellikleri bu çalışma kapsamında tasarlanan katı atık toplama aracının teknik özellikleri ile karşılaştırmalı olarak Tablo 2'de verilmektedir.

\section{Materyal ve Metod}

Katı atık toplama aracının tasarımında Strathclyde Üniversitesi öğretim üyelerinden Prof. Stuard Pugh tarafından geliştirilen ve Toplam Tasarım adı verilen tasarım metodu kullanılmıștır [8]. Pugh'a göre pazar/kullanıcı ihtiyacının tanımlanmasından ihtiyacı karşılayacak başarılı bir ürünün satışına kadar olan süreçte gerekli olan sistematik aktivitelerin bütünü Toplam Tasarım'dır. Toplam Tasarım'da mühendislik ve mühendislik dışı birçok alandan girdiye ihtiyaç duyulmakta ve bu girdiler sadece tasarlanması düşünülen ürüne özel olan bir karışım şeklinde olmaktadır (Şekil 9).

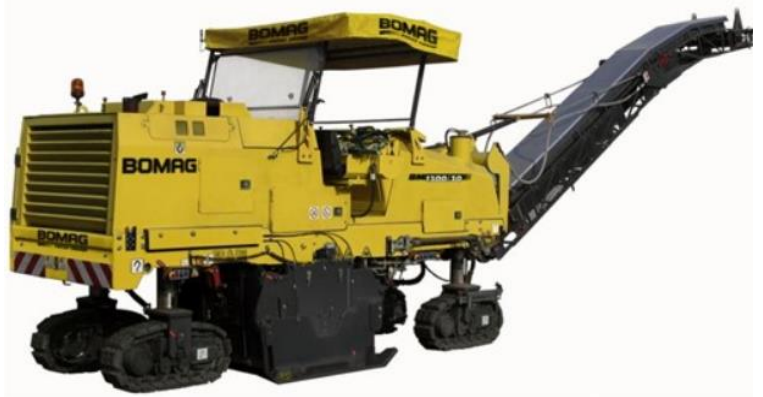

Şekil 6. Asfalt kazıma makinası [5]

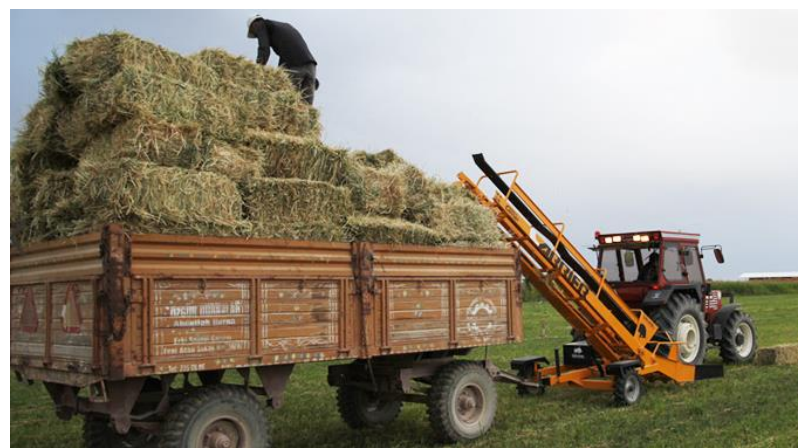

Şekil 7. Balya yükleme makinası [6]

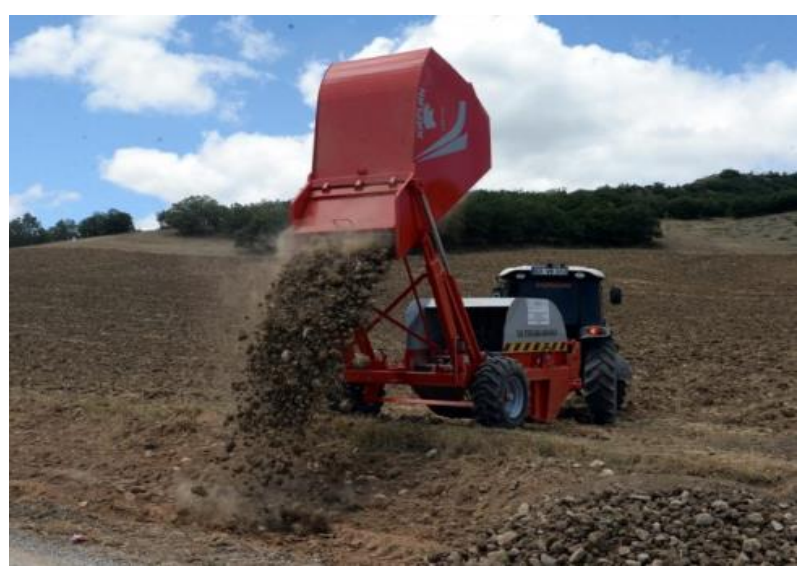

Şekil 8. Taş toplama makinası [7]

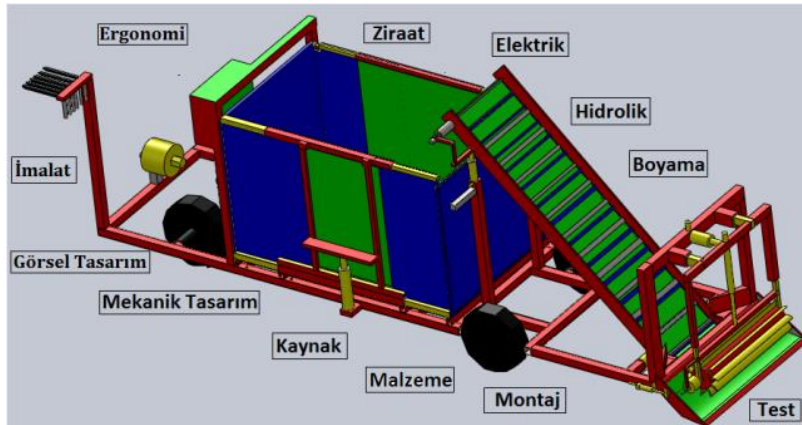

Şekil 9. Katı atık toplama aracı için gerekli olan disiplin girdileri

Toplam tasarım, faaliyetlerinin bütünü basamaklardan oluşan bir merdiven olarak yorumlanabilir ve toplam tasarım basamakları bütün 
tasarımlar için zorunludur. Şekil 10, ana hatlarıyla Toplam Tasarım'ın basamaklarını göstermektedir.

Tablo 2. Katı atık toplama aracı ile benzer çalışma prensibine sahip makinaların karşılaştırılması

\begin{tabular}{|c|c|c|c|c|}
\hline & $\begin{array}{c}\text { Asfalt } \\
\text { Kazıma } \\
\text { Makinası }\end{array}$ & $\begin{array}{c}\text { Balya } \\
\text { Yükleme } \\
\text { Makinası }\end{array}$ & $\begin{array}{c}\text { Taş } \\
\text { Toplama } \\
\text { Makinası }\end{array}$ & $\begin{array}{c}\text { Katı Atık } \\
\text { Toplama } \\
\text { Aracı }\end{array}$ \\
\hline Çalışma Hızı & $\begin{array}{c}0.5 \\
\mathrm{~m} / \mathrm{sn}\end{array}$ & $\begin{array}{c}1 \\
\mathrm{~m} / \mathrm{sn}\end{array}$ & $\begin{array}{c}0.5 \\
\mathrm{~m} / \mathrm{sn}\end{array}$ & $\begin{array}{c}3 \\
\mathrm{~m} / \mathrm{sn}\end{array}$ \\
\hline $\begin{array}{l}\text { Ağırlık (araç } \\
\text { dahil tüm } \\
\text { sistem) }\end{array}$ & $\begin{array}{c}30 \\
\text { ton }\end{array}$ & $\begin{array}{c}3200 \\
\mathrm{~kg}\end{array}$ & $\begin{array}{c}5500 \\
\mathrm{~kg}\end{array}$ & $300 \mathrm{~kg}$ \\
\hline Güç Kaynağl & $\begin{array}{c}500 \mathrm{BG} \\
\text { (Min.) }\end{array}$ & $\begin{array}{l}50 \mathrm{BG} \\
\text { (Min.) }\end{array}$ & $\begin{array}{c}100 \mathrm{BG} \\
\text { (Min.) }\end{array}$ & $\begin{array}{l}15 \mathrm{BG} \\
\text { (Min.) }\end{array}$ \\
\hline $\begin{array}{l}\text { Yükleme } \\
\text { kapasitesi }\end{array}$ & $\begin{array}{c}1000 \\
\mathrm{~kg} / \mathrm{dak}\end{array}$ & $\begin{array}{c}120 \\
\mathrm{~kg} / \mathrm{dak}\end{array}$ & $\begin{array}{c}750 \\
\mathrm{~kg} / \mathrm{dak}\end{array}$ & $\begin{array}{c}65 \\
\mathrm{~kg} / \text { dak }\end{array}$ \\
\hline $\begin{array}{l}\text { Çalışma } \\
\text { Alanı } \\
\text { Genişliği }\end{array}$ & $\begin{array}{c}5 \mathrm{~m} \\
\text { (Min.) }\end{array}$ & $\begin{array}{c}5 \mathrm{~m} \\
\text { (Min.) }\end{array}$ & $\begin{array}{c}3 \mathrm{~m} \\
\text { (Min.) }\end{array}$ & $\begin{array}{c}1 \mathrm{~m} \\
\text { (Min.) }\end{array}$ \\
\hline
\end{tabular}

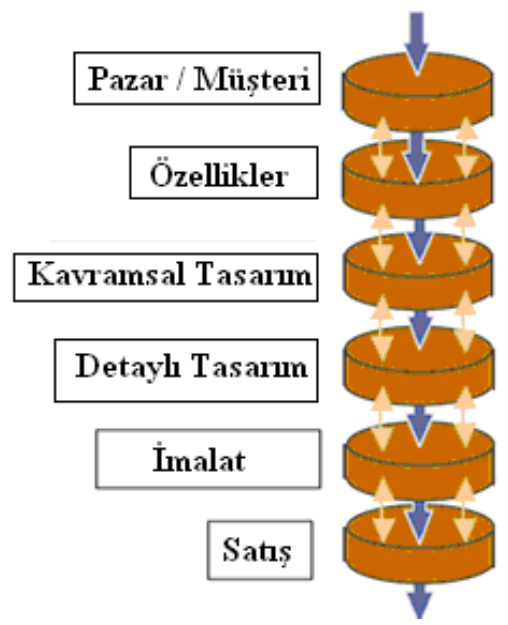

Şekil 10. Toplam tasarım basamakları [8]

$\mathrm{Bu}$ çalışmada, Toplam Tasarım metoduna göre, öncelikle piyasada satışı yapılan ve yaygın olarak kullanılan katı atık toplama araçlarının ve benzer araçların özellikleri incelenmiş, bir marka-özellikler Tablosi oluşturulmuş ve araçların karşılaştırılması yapılmıştır. Daha sonra tasarımı yapılacak katı atık toplama aracının sahip olması gereken teknik özellikler maddeler halinde listelenmiş ve araç üzerinde bulunan bölümler fonksiyonlar halinde belirtilmiştir. Her bir fonksiyon için gerekli olan teknik özellikleri karşılayacak şekilde konseptler oluşturmak için beyin fırtınası yapılmıștır. Oluşturulan konseptler Pugh diyagramı yardımıyla her fonksiyonun kendine özgü kriterleri baz alınarak değerlendirilmiş ve en yüksek puanı alan konsept detay tasarım için seçilmiştir.

Detay tasarım aşamasında aracın her bir bölümünün teknik resimleri çizilerek katı modelleri oluşturulmuş ve sanal montajı gerçekleștirilmiştir. Belirlenmiş olan teknik özellikleri karşılayacak çapa makinası, hidromotor, hidrolik dişli pompa, hidrolik piston gibi bileşenler için piyasa araştırması yapılmıştır. Bu araştırmalar sonrasında en uygun parçalar seçilerek satın alınmış ve tasarım boyutlarına uygun olarak imal edilmiş ana gövde üzerine monte edilmiştir. İmalat öncesinde ana gövde için statik yükleme şartlarında Ansys Workbench ticari yazılımı kullanılarak gerilme analizi yapılmıştır.

İmalatı yapılmış olan prototip katı atık toplama aracı hafif ve ağır katı atıklarla $150 m^{2}-250 m^{2}$ lik alanlarda teste tabi tutulmuş ve var olan eksiklikler tespit edilmiştir. Daha sonra katı atık toplama aracının tespit edilen eksiklikleri tamamlanarak son halini almıştır.

\section{Kavramsal Tasarım}

Bu çalışma kapsamında tasarlanan katı atık toplama aracı; toplama bölümü, yükleme bölümü, römork bölümü ve çapa makinasının çıkarılıp takılacağı motor bölümü olmak üzere dört bölümden oluşmaktadır. Katı atık toplama aracının sahip olması istenen teknik özellikler şunlardır:

1. Güç kaynağı : standart çapa makinası

2. Çapa makinasına montaj : pimli geçme

3. Araç çalışma alanı : $150-250 \mathrm{~m}^{2}$

4. Kumanda bölümü yüksekliği : $80-120 \mathrm{~cm}$

5. Katı atık yükleme yüksekliği : $80 \mathrm{~cm}$

6. Kürüme bölümü genişliği : $60 \mathrm{~cm}$

7. Konveyör bant yükleme hızı :0,5 m/sn

8. Konveyör bant yükleme ağırlığı : 70-100 kg/dak

9. Römork uzunluğu : $80-120 \mathrm{~cm}$

10. Römork kapasitesi : $700 \mathrm{~kg}$

11. Römork yana boşaltma açısı : $45^{\circ}-60^{\circ}$

12. Römork doldurma süresi : 7-10 dak

13. Römork boşaltma süresi : 0.5-1 dak

\subsection{Konsept geliştirme}

$\mathrm{Bu}$ kısımda araç üzerinde bulunan bölümler fonksiyonlar halinde belirtilmiş, avantaj ve dezavantajları açıklanmıştır. Belirlenen fonksiyonlar şunlardır: 1. Motor bölümü, 2. Römork bölümü, 3 . Yükleme bölümü, 4. Toplama bölümü, 5. Hidrolik piston

\subsection{Konseptlerin değerlendirilmesi}

Konseptler Pugh diyagramı yardımıyla her fonksiyonun kendine özgü kriterleri baz alınarak değerlendirilmiştir.

Değerlendirmede Tablo 3' de gösterilen performans değerine göre belirlenen oranlar ve proje içerisindeki yüzdelik önemleri kullanılmış ve her bir fonksiyon için en yüksek puanı alan konsept seçilmiştir. Seçilen konseptler fonksiyonlara ait konsept Tablolerinde yeşile boyanarak gösterilmiştir.

\subsubsection{Motor bölümü}

Motor bölümü çapa makinası, kumanda kolları, tahrik tekerleri, araç yönlendirme kolları ve yă deposundan oluşmaktadır. Çapa makinası aracın 
hareketi ve diğer bölümlerin çalışması için gerekli olan gücü sağlamaktadır. Bu bölümde çapa makinası sabit olmayıp istenildiği zaman çlkarılıp takılabilmektedir. Araca ait hidromotorlar ve hidrolik pistonların çalışması çapa makinasının kuyruk mili çıkışına kaplinle bağlı olan dişli pompa sayesinde sağlanmaktadır.

Tablo 3. Performans değerleri ve oranları

\begin{tabular}{cc}
\hline Performans değeri & Oran \\
\hline Referans göre daha kötü & 1 \\
Referansa göre kötü & 2 \\
Referans ile aynı & 3 \\
Referansa göre iyi & 4 \\
Referansa göre çok iyi & 5 \\
\hline
\end{tabular}

Çapa makinasının araçtaki konumu ile ilgili olan motor bölümü çalışmaları için üç tip konsept sunulmuştur. $\mathrm{Bu}$ konseptlere ait avantaj ve dezavantajlar; montaj kabiliyeti, manevra kabiliyeti, tork seviyesi, tekerlek deformasyonu, maliyet, zemine bağlı hareket, ağırlık gibi bu montaja özgü kriterler yardımıyla açıklanmıștır (Tablo 4). Bu kriterler aynı zamanda Pugh diyagramı yardımıyla en iyi çapa makinası montaj yerini belirlemede kullanılan kriterlerdir.
Karşılaştırma sonucunda çapa makinasının aracın arka tarafına yerleştirilmesi, referans alınan sabit montaja göre zemine bağlı hareket, manevra kabiliyeti, maliyet ve montaj kabiliyeti kriterlerinde öne çıkmış ve bu bölüm için en iyi çözüm olarak seçilmiştir. Seçimde tork seviyesi, tekerlek deformasyonu ve eğime bağlı hareket kriterleri negatif etki oluşturmuştur.

\subsubsection{Römork bölümü}

Römork bölümü katı atıkların yüklendiği bölümdür. $\mathrm{Bu}$ bölümün hacmi ihtiyaç durumuna göre genişletilebilmektedir. Römork bölümünün genişletilmesi için birbiri içine geçen profiller ve kanallı kapaklar kullanılmaktadır.

Römork bölümünün hacminin genişleme yönüyle ilgili olan römork bölümü çalışmaları için üç tip konsept sunulmuştur. Bu konseptlere ait avantaj ve dezavantajlar; denge, eğime bağlı hareket, montaj kabiliyeti, manevra kabiliyeti, ağırlık gibi bu montaja özgü kriterler yardımıyla açıklanmıştır (Tablo 5). Bu kriterler aynı zamanda Pugh diyagramı yardımıyla en iyi römork genişleme yönünü belirlemede kullanılan kriterlerdir.

Tablo 4. Motor bölümü için en iyi konsept seçimi

\begin{tabular}{|c|c|c|c|c|c|c|c|}
\hline \multirow[b]{2}{*}{ Değerlendirme kriterleri } & \multirow[b]{2}{*}{ Önem } & \multicolumn{2}{|c|}{$\begin{array}{l}\text { Sabit montaj } \\
\text { (REFERANS) }\end{array}$} & \multicolumn{2}{|c|}{ Ön tarafa montaj } & \multicolumn{2}{|c|}{$\begin{array}{c}\text { Arka tarafa } \\
\text { montaj }\end{array}$} \\
\hline & & Oran & Önem & Oran & Önem & Oran & Önem \\
\hline Montaj kabiliyeti & $20 \%$ & 3 & 0.6 & 4 & 0.8 & 4 & 0.8 \\
\hline Manevra kabiliyeti & $25 \%$ & 3 & 0.75 & 4 & 1 & 5 & 1.25 \\
\hline Maliyet & $10 \%$ & 3 & 0.3 & 4 & 0.4 & 4 & 0.4 \\
\hline Tork seviyesi & $10 \%$ & 3 & 0.3 & 2 & 0.2 & 2 & 0.2 \\
\hline Ağırlık & $5 \%$ & 3 & 0.15 & 3 & 0.15 & 3 & 0.15 \\
\hline Eğime bağlı hareket & $10 \%$ & 3 & 0.15 & 2 & 0.2 & 2 & 0.2 \\
\hline Zemine bağlı hareket & $10 \%$ & 3 & 0.3 & 4 & 0.4 & 4 & 0.4 \\
\hline $\begin{array}{c}\text { Tekerleklerin deformasyonu } \\
\text { Toplam } \\
\text { Siralama } \\
\text { Sonuç }\end{array}$ & $10 \%$ & & değil & Uyg & değil & 2 & 0.2 \\
\hline
\end{tabular}

Tablo 5. Römork bölümü için en iyi konsept seçimi

\begin{tabular}{|c|c|c|c|c|c|c|c|}
\hline \multirow[b]{2}{*}{ Değerlendirme kriterleri } & \multirow[b]{2}{*}{ Önem } & \multicolumn{2}{|c|}{$\begin{array}{l}\text { Yan tarafa } \\
\text { genişleme } \\
\text { (REFERANS) }\end{array}$} & \multicolumn{2}{|c|}{$\begin{array}{l}\text { Her iki tarafa } \\
\text { genişleme }\end{array}$} & \multicolumn{2}{|c|}{$\begin{array}{l}\text { Arka tarafa } \\
\text { genişleme }\end{array}$} \\
\hline & & Oran & Önem & Oran & Önem & Oran & Önem \\
\hline Montaj kabiliyeti & $20 \%$ & 3 & 0.6 & 2 & 0.4 & 4 & 0.8 \\
\hline Manevra kabiliyeti & $25 \%$ & 3 & 0.75 & 2 & 0.5 & 5 & 1 \\
\hline Maliyet & $10 \%$ & 3 & 0.3 & 2 & 0.2 & 4 & 0.4 \\
\hline Mukavemet & $15 \%$ & 3 & 0.45 & 2 & 0.3 & 4 & 0.6 \\
\hline Ağırlık & $5 \%$ & 3 & 0.15 & 4 & 0.2 & 2 & 0.1 \\
\hline Eğime bağlı hareket & $5 \%$ & 3 & 0.15 & 4 & 0.2 & 3 & 0.15 \\
\hline Denge & $20 \%$ & 3 & 0.6 & 4 & 0.8 & 4 & 0.8 \\
\hline \multicolumn{2}{|l|}{ Toplam } & \multicolumn{2}{|c|}{3} & \multicolumn{2}{|c|}{2.6} & \multicolumn{2}{|c|}{3.85} \\
\hline \multicolumn{2}{|l|}{ Siralama } & \multirow{2}{*}{\multicolumn{2}{|c|}{$\frac{2}{\text { Uvgun değil }}$}} & \multirow{2}{*}{\multicolumn{2}{|c|}{$\begin{array}{c}3 \\
\text { Uygun değil }\end{array}$}} & \multirow{2}{*}{\multicolumn{2}{|c|}{$\begin{array}{c}1 \\
\text { Uvgun }\end{array}$}} \\
\hline Sonuç & & & & & & & \\
\hline
\end{tabular}


Tablo 6. Yükleme bölümü için en iyi konsept seçimi

\begin{tabular}{|c|c|c|c|c|c|c|c|}
\hline \multirow[b]{2}{*}{ Değerlendirme kriterleri } & \multirow[b]{2}{*}{ Önem } & \multicolumn{2}{|c|}{$\begin{array}{c}\text { Kepçe sistemi } \\
\text { (REFERANS) }\end{array}$} & \multicolumn{2}{|c|}{$\begin{array}{l}\text { Elevatör } \\
\text { sistemi }\end{array}$} & \multicolumn{2}{|c|}{$\begin{array}{c}\text { Konveyör bant } \\
\text { sistemi }\end{array}$} \\
\hline & & Oran & Önem & Oran & Önem & Oran & Önem \\
\hline Montaj kabiliyeti & $10 \%$ & 3 & 0.3 & 2 & 0.2 & 5 & 0.5 \\
\hline Maliyet & $10 \%$ & 3 & 0.3 & 3 & 0.3 & 2 & 0.2 \\
\hline Ağırlık & $5 \%$ & 3 & 0.15 & 2 & 0.1 & 3 & 0.15 \\
\hline Mukavemet & $10 \%$ & 3 & 0.3 & 3 & 0.3 & 4 & 0.4 \\
\hline $\mathrm{Hiz}$ & $10 \%$ & 3 & 0.3 & 4 & 0.4 & 5 & 0.5 \\
\hline Hidrolik sistem & $10 \%$ & 3 & 0.3 & 4 & 0.4 & 4 & 0.4 \\
\hline Yük kapasitesi & $20 \%$ & 3 & 0.6 & 4 & 0.8 & 4 & 0.8 \\
\hline Koordineli çalışma & $25 \%$ & 3 & 0.75 & 4 & 1 & 5 & 1.25 \\
\hline Toplam & & \multicolumn{2}{|c|}{3} & \multicolumn{2}{|c|}{2.5} & \multicolumn{2}{|c|}{4.2} \\
\hline Siralama & & \multicolumn{2}{|c|}{2} & \multicolumn{2}{|c|}{3} & \multirow{2}{*}{\multicolumn{2}{|c|}{1}} \\
\hline Sonuç & & \multicolumn{2}{|c|}{ Uygun değil } & \multicolumn{2}{|c|}{ Uygun değil } & & \\
\hline
\end{tabular}

Karşılaştırma sonucunda römork bölümünün referans alınan yan tarafa genişlemesine göre römorkun arka tarafa genişlemesi manevra kabiliyeti, montaj kabiliyeti, maliyet, mukavemet ve denge gibi kriterlerde öne çıkarak bu bölüm için en iyi çözüm olarak seçilmiştir. Ağırlık bu bölüm için dezavantaj olarak negatif etki oluşturmuştur.

\subsubsection{Yükleme bölümü}

Yükleme bölümü, toplama bölümümden gelen katı atıkların elevatör, kepçe veya konveyör bant yardımıyla römork bölümüne aktarıldığı bölümdür.

Yükleme bölümünün katı atığı dolduracak sistemi ile ilgili olan yükleme bölümü çalışmaları için üç tip konsept sunulmuştur. Bu konseptlere ait avantaj ve dezavantajlar; montaj kabiliyeti, ağırlık, mukavemet, yük kapasitesi, hız gibi bu montaja özgü kriterler yardımıyla açıklanmıştır (Tablo 6). Bu kriterler aynı zamanda Pugh diyagramı yardımıyla en iyi yükleme sistemini belirlemede kullanılan kriterlerdir.

Karşılaştırma sonucunda referans alınan kepçe sistemine göre konveyör bant sistemi montaj kabiliyeti, mukavemet, hız, hidrolik sistem, yük kapasitesi ve koordineli çalışma kriterlerinde öne çlkmış ve bölüm için en iyi çözüm olarak seçilmiştir. Seçimde maliyet negatif etki oluşturmuştur.

\subsubsection{Toplama bölümü}

Toplama bölümünde zeminden toplanan katı atıkların yükleme sistemi üzerine aktarılmasına yardımcı olacak sistem bulunmaktadır. $\mathrm{Bu}$ sistem yükleme sistemine göre değişim gösterebilmektedir. Zeminden toplanan katı atıkların yükleme sistemine aktarılması ile ilgili toplama bölümü çalışmaları için üç tip konsept sunulmuştur. Bu konseptlere ait avantaj ve dezavantajlar; ağırlık, maliyet, zemine bağlı hareket, yük kapasitesi, hız gibi bu montaja özgü kriterler yardımıyla açıklanmıştır (Tablo 7). Bu kriterler aynı zamanda Pugh diyagramı yardımıyla en iyi toplama sistemini belirlemede kullanılan kriterlerdir.

Karşılaştırma sonucunda referans alınan kapaklı kürüme sistemine göre kanatlı döner sistem zemine bağlı hareket, yük kapasitesi, hız ve konstrüksiyon kriterlerinde öne çıkmış ve bu bölüm için en iyi çözüm olarak seçilmiştir. Seçimde ağırlık, maliyet ve montaj kabiliyeti kriterleri negatif etki oluşturmuştur.

\subsubsection{Hidrolik piston}

Römorka monte edilen hidrolik piston, katı atıkla dolan römorku sağ veya sol tarafına boşaltmak için kullanılmaktadır.

Hidrolik piston konumu için üç tip konsept sunulmuştur. $\mathrm{Bu}$ konseptlere ait avantaj ve dezavantajlar; montaj kabiliyeti, ağırlık, yük kapasitesi, mukavemet gibi bu montaja özgü kriterler yardımıyla açıklanmıştır (Tablo 8).

Bu kriterler aynı zamanda Pugh diyagramı yardımıyla en iyi hidrolik piston konumu belirlemede kullanılan kriterlerdir.

Karşılaştırma sonucunda "alt tarafa yatay pozisyonda yerleștirme", referans alınan "alt tarafa dikey pozisyonda yerleștirme" ye göre konstrüksiyon, mukavemet ve yük kapasitesi kriterlerinde öne çıkmış ve bu bölüm için en iyi çözüm olarak seçilmiştir. Seçimde montaj kabiliyeti ve maliyet kriterleri negatif etki oluşturmuştur.

\subsection{En iyi konsept}

Konsept geliştirme sürecinde ortaya atılan konseptlerin değerlendirilmesi ile detay tasarımına başlanacak en iyi konsept belirlenmiştir. Seçilen en iyi konseptler morfolojik Tablo şeklinde gösterilmiştir (Tablo 9). En iyi çözümleri içeren araç montajı ise Şekil 11'de gösterilmiştir. 
Tablo 7. Toplama bölümü için en iyi konsept seçimi

\begin{tabular}{|c|c|c|c|c|c|c|c|}
\hline \multirow[b]{2}{*}{ Değerlendirme kriterleri } & \multirow[b]{2}{*}{ Önem } & \multicolumn{2}{|c|}{$\begin{array}{l}\text { Kapaklı kürüme } \\
\text { sistemi } \\
\text { (REFERANS) }\end{array}$} & \multicolumn{2}{|c|}{ Pistonlu çektirme } & \multicolumn{2}{|c|}{ Kanatlı döner sistem } \\
\hline & & Oran & Önem & Oran & Önem & Oran & Önem \\
\hline Ağırlık & $15 \%$ & 3 & 0.45 & 3 & 0.45 & 2 & 0.3 \\
\hline Maliyet & $5 \%$ & 3 & 0.15 & 2 & 0.1 & 2 & 0.1 \\
\hline Montaj kabiliyeti & $15 \%$ & 3 & 0.45 & 2 & 0.3 & 2 & 0.3 \\
\hline Zemine bağlı hareket & $15 \%$ & 3 & 0.45 & 4 & 0.6 & 4 & 0.6 \\
\hline Yük kapasitesi & $15 \%$ & 3 & 0.45 & 2 & 0.3 & 5 & 0.75 \\
\hline $\mathrm{Hiz}$ & $15 \%$ & 3 & 0.45 & 2 & 0.3 & 5 & 0.75 \\
\hline Konstrüksiyon & $20 \%$ & 3 & 0.6 & 2 & 0.4 & 4 & 0.8 \\
\hline Toplam & & & & & & & \\
\hline Siralama & & & & & & & \\
\hline Sonuç & & Uys & eğil & & eğil & & \\
\hline
\end{tabular}

Tablo 8. Hidrolik piston konumu için en iyi konsept seçimi

\begin{tabular}{|c|c|c|c|c|c|c|c|}
\hline \multirow[b]{2}{*}{ Değerlendirme kriterleri } & \multirow[b]{2}{*}{ Önem } & \multicolumn{2}{|c|}{$\begin{array}{l}\text { Alt tarafa dikey } \\
\text { pozisyon } \\
\text { (REFERANS) }\end{array}$} & \multicolumn{2}{|c|}{$\begin{array}{l}\text { Yan tarafa dikey } \\
\text { pozisyon }\end{array}$} & \multicolumn{2}{|c|}{$\begin{array}{l}\text { Alt tarafa yatay } \\
\text { pozisyon }\end{array}$} \\
\hline & & Oran & Önem & Oran & Önem & Oran & Önem \\
\hline Montaj kabiliyeti & $10 \%$ & 3 & 0.3 & 4 & 0.4 & 2 & 0.2 \\
\hline Maliyet & $10 \%$ & 3 & 0.3 & 4 & 0.4 & 2 & 0.2 \\
\hline Ağırlık & $15 \%$ & 3 & 0.45 & 3 & 0.45 & 3 & 0.45 \\
\hline Yük kapasitesi & $20 \%$ & 3 & 0.6 & 2 & 0.4 & 4 & 0.8 \\
\hline Konstrüksiyon & $10 \%$ & 3 & 0.3 & 2 & 0.2 & 4 & 0.4 \\
\hline Denge & $25 \%$ & 3 & 0.75 & 3 & 0.75 & 3 & 0.75 \\
\hline Mukavemet & $10 \%$ & 3 & 0.3 & 2 & 0.2 & 5 & 0.5 \\
\hline Toplam & & \multirow{2}{*}{\multicolumn{2}{|c|}{$\begin{array}{l}3 \\
2\end{array}$}} & \multicolumn{2}{|c|}{2.8} & \multicolumn{2}{|c|}{3.3} \\
\hline Siralama & & & & & & & \\
\hline Sonuç & & \multicolumn{2}{|c|}{ Uygun değil } & \multicolumn{2}{|c|}{ Uygun değil } & \multicolumn{2}{|c|}{ Uygun } \\
\hline
\end{tabular}

Tablo 9. En iyi çözümler için morfolojik Tablo

\begin{tabular}{cccc}
\hline Fonksiyon & & Konsept & \\
\hline Motor bölümü & Sabit montaj & Ön tarafa montaj & Arka tarafa montaj \\
Römork bölümü & Yan tarafa genişleme & Her iki tarafa genişleme & Arka tarafa genişleme \\
Yükleme bölümü & Konveyör bant sistemi & Kepçe sistemi & Elevatör sistemi \\
Toplama bölümü & Pistonlu çektirme sistemi & Kapaklı kürüme sistemi & Kanatlı döner sistem \\
Hidrolik piston & Alt tarafa dikey & Yan tarafa dikey & Alt tarafa yatay \\
& pozisyonda montaj & pozisyonda montaj & pozisyonda montaj \\
\hline
\end{tabular}

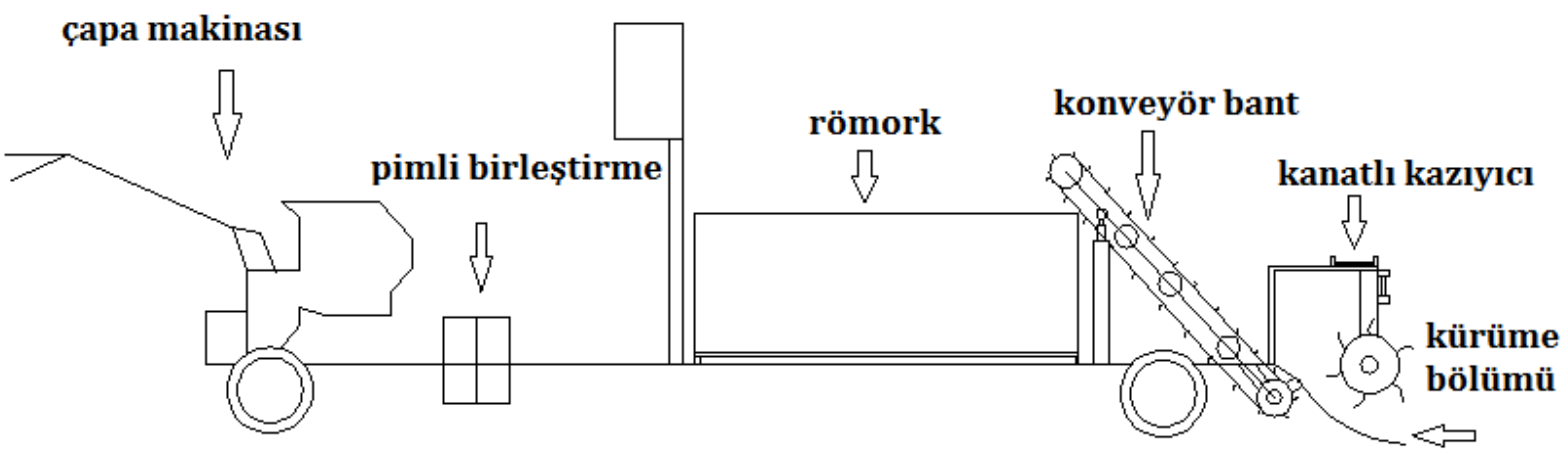

Şekil 11. En iyi konsept

\section{Detay Tasarım}

Detay tasarım aşamasında normal tasarım aşamasında olduğu gibi bileşenlerin birbiriyle olan uyumları göz önünde bulundurularak detay tasarım yapılmıştir. Teknik şartname gereksinimleri doğrultusunda en iyi konsepte ait teknik hesaplamalar ve analizler yapılmış, parça seçimleri tamamlanmıștır.

\subsection{Hidromotor seçimi}

Şekil 12' de konveyör bant sistemi için gerekli güç satıcı firmanın geliştirdiği program yardımıyla 
minimum 0,56 kW olarak hesaplanmıştır [9]. Hesaplanan güç değerine bağlı olarak seçim için değerlendirilen hidromotorların teknik özellikleri Tablo 10'da verilmektedir.

Tablo 10'dan hesaplanan güç değerine en yakın değer olarak maksimum çıkış gücü $4 \mathrm{~kW}$ olan BMP-400 model hidromotor seçilmiştir.

Tablo 10. Hidromotorun teknik özellikleri [10]

\begin{tabular}{lllll}
\hline \multirow{2}{*}{ MODEL } & BMP & BMP & BMP & BMP \\
& 200 & 250 & 315 & 400 \\
\hline Deplasman & 196,4 & 241,8 & 317.3 & 392,9 \\
Basınç (bar) & 140 & 110 & 90 & 70 \\
Mak. Tork (Nm) & 365 & 378 & 378 & 378 \\
Hız (dev/dak) & $7-$ & $5-$ & $5-192$ & $5-$ \\
Debi (lt/dak) & 310 & 250 & 155 \\
Güç (kW) & 60 & 60 & 60 & 60 \\
Ağırlık (kg) & 8 & 6 & 5 & $\mathbf{4}$ \\
\hline
\end{tabular}

Katı atık toplama aracında biri konveyör bant sisteminde, diğeri toplama sisteminde olmak üzere iki adet hidromotor gerekmektedir ve özellikleri aynı olacaktır. Hidromotor yağ iletim hacmi (dişli pompadan gelen) Denklem 1 kullanılarak bulunur.

$$
\boldsymbol{T}=\frac{\mathrm{V} * \Delta \mathbf{p} * \boldsymbol{\eta}}{20 \pi}
$$

Burada $\mathrm{T}$ hidromotorun verdiği tork $(\mathrm{Nm}), \mathrm{V}$ hidromotorun iletim hacmi $\left(\mathrm{cm}^{3} / \mathrm{dev}\right), \Delta \mathrm{p}$ hidromotorun kullandığı basınç (giriş ve çıkış basınç farkl, bar) ve $\eta$ hidromotor verimidir.
Denklem 1'de seçilen hidromotor için T değeri 378 $\mathrm{Nm}, \Delta \mathrm{p}$ değeri 0.5 bar ve $\eta$ değeri 0.95 alındığında;

$$
378 * 10^{2}=\frac{V \times 0.5 \times 0.95}{20 \pi}
$$

Hidromotorun iletim hacmi $\mathrm{V}=5 \mathrm{~cm}^{3} / \mathrm{dev}$ bulunur. Hesaplanan değer 1 adet hidromotor içindir. Buna göre seçilecek olan dişli pompanın minimum 5 $\mathrm{cm}^{3} / \mathrm{dev}$ sağlayacak bir pompa olması gerekmektedir.

Konveyör bant çalışma açısı $45^{\circ}$ olarak belirlendiğinden çavuş bant (tırnak yüksekliği $15 \mathrm{~mm}$ olan bant) tipi seçilmiştir. Bantın uzunluğu 2,5 metre olup yerden toplanan atıkların bant kenarından taşmadan römorka aktarılması için rulolarla bantın yanlarına eğim verilmiştir.

\subsection{Hidrolik piston seçimi}

Römork bölümünde kullanılacak ve maksimum 7500 N yükü kaldıracak olan hidrolik pistonun seçimi için Denklem 3 kullanılır:

$$
\mathbf{F}=\mathbf{p} * \mathbf{A} * \mathbf{n} * \mathbf{1 0}
$$

Burada F pistona gelen yük (N), p sıvı basıncı (bar), A piston kesit alanı $\left(\mathrm{cm}^{2}\right)$, d piston çapı $(\mathrm{cm})$ ve $n$ silindirin etki derecesidir.

Denklem 3'de F değeri 7500 N, p değeri 150 bar (dişli pompanın maksimum çıkıș basıncı 250 bar) ve $n$ değeri 1 alındığında;

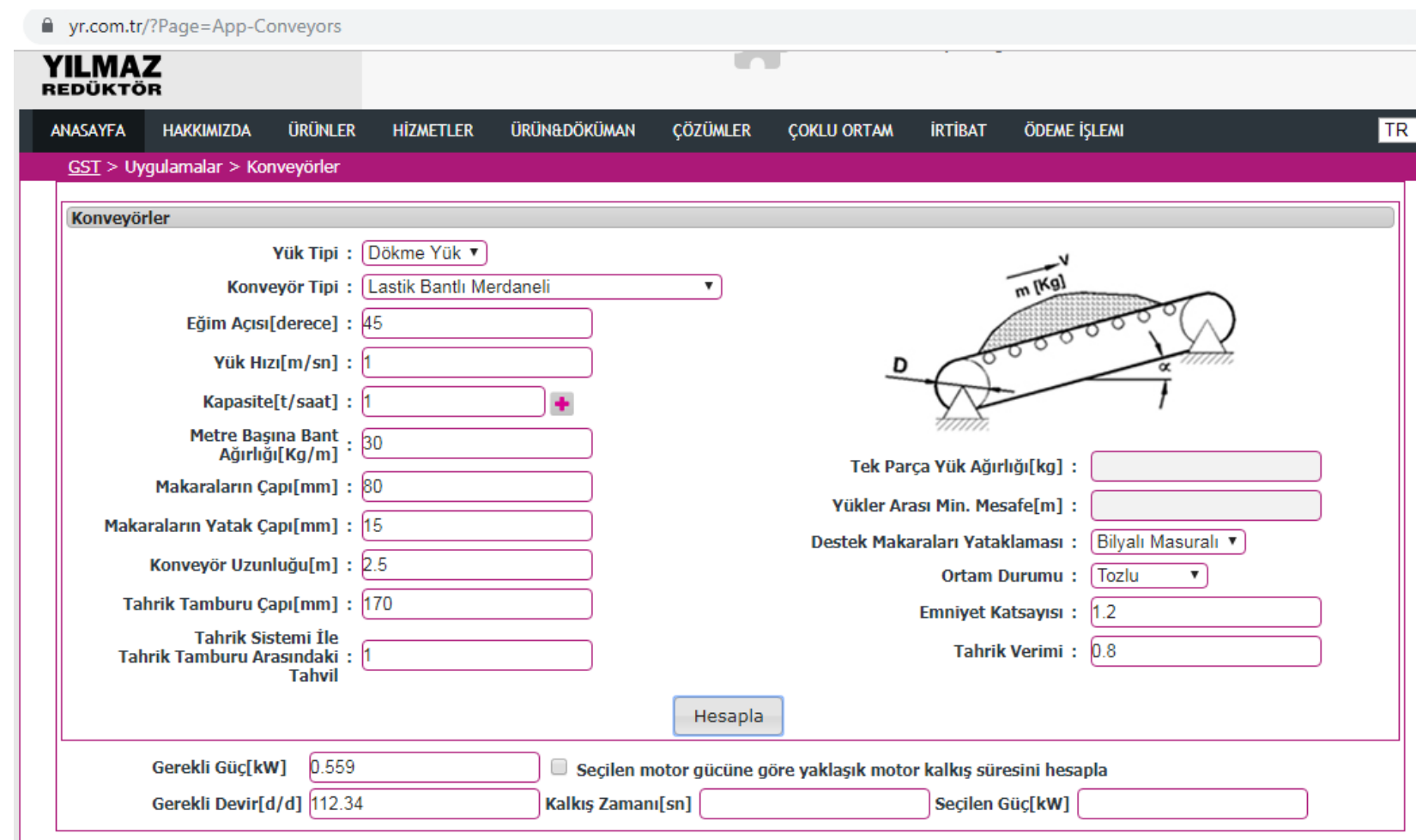

Şekil 12. Konveyör bant sistemi için gerekli olan hidromotor gücünün belirlenmesi [9] 


$$
7500=150 *\left(3,14 * \frac{d^{2}}{4}\right) * 1 * 10
$$

piston çapı, $\mathrm{d}=2.52 \mathrm{~cm}$ bulunur. $\mathrm{Bu}$ durumda en yakın standart değer olarak çapı $3.2 \mathrm{~cm}$ olan bir hidrolik silindir römork sistemi için uygun olacaktır. Seçilen hidrolik pistonun teknik özellikleri şu şekildedir: çap $32 \mathrm{~mm}$, strok boyu $700 \mathrm{~mm}$, maksimum çalışma basınci 150 bar. Hidrolik piston maksimum 0.5 m/sn hızda çalışacak olup gerektiğinde hızın düşürülmesi mümkündür. Hidrolik pistonun şase ve römorka bağlantı şekli oynar mafsallı olacaktır.

\subsection{Dişli pompa seçimi}

Seçilen hidromotor ve piston özelliklerine göre uygun bir dişli pompanın debisi şu formülle bulunmaktadır:

$$
Q=\frac{\text { V.n.n }}{1000}
$$

Burada Q pompa debisi (lt/dak), V pompa iletim hacmi $\left(\mathrm{cm}^{3} / \mathrm{dev}\right), \mathrm{n}$ kullanılan elektrik motorunun devri (dev/dak) ve $\eta$ pompa volümetrik verimidir.

Araçtaki bir hidromotorun çalışması için gerekli iletim hacmi $\mathrm{V}=5 \mathrm{~cm}^{3} / \mathrm{dev}$ olarak belirlenmiștir. Pompanın seçiminde aracın yokuş yukarı çalışması, çalışma zemini şartları ve çapa makinasının motor performansı gibi etkiler göz önünde bulundurularak dişli pompa Tablosinden (Tablo 11) yağ iletim hacmi $9,5 \mathrm{~cm}^{3} / \mathrm{dev}$ olan pompa seçilmiştir.

\begin{tabular}{|c|c|c|c|}
\hline Model & $\begin{array}{l}\text { İletim } \\
\text { hacmi, } \\
\mathrm{cm}^{3} / \mathrm{dev}\end{array}$ & $\begin{array}{c}\text { Debi } \\
(1500 \\
\text { dev/dak) } \\
\text { lt/dak }\end{array}$ & $\begin{array}{l}\text { Mak. çıkış } \\
\text { basıncl, } \\
\text { bar }\end{array}$ \\
\hline $1 \mathrm{PN}-040$ & 4 & 5,7 & 250 \\
\hline 1PN-061 & 6,1 & 8,7 & 250 \\
\hline 1PN-082 & 8,2 & 11,8 & 250 \\
\hline 1PN-095 & 9,5 & 13,6 & 250 \\
\hline 1PN-119 & 11,9 & 17,1 & 250 \\
\hline 1PN-135 & 13,5 & 19,4 & 250 \\
\hline $\begin{array}{l}\text { Tüm modeller } \\
\text { dev/dak'dır. }\end{array}$ & 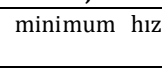 & 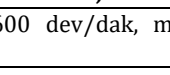 & 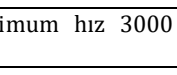 \\
\hline
\end{tabular}

$\underline{\text { Tablo 11. Dișli pompa özellikleri [10] }}$

Denklem 5' de V değeri $9.5 \mathrm{~cm}^{3} / \mathrm{dev}$, n değeri 1500 $\mathrm{dev} /$ dak ve $\eta$ değeri 0.95 alındığında;

$$
Q=\frac{9,5 * 1500 * 0,95}{1000}
$$

pompa debisi, $\mathrm{Q}=13.56 \mathrm{lt} /$ dak bulunur.

Kürüme sistemi ile konveyör bant sisteminin hidromotorlarının aynı anda çalışması gerektiğinden her iki hidromotor ve römork hidrolik pistonu için üç ayrı pompa kullanılması kararlaştırılmıştır. Dişli pompaların üçü de aynı özellikte olduğundan üç ayrı pompa yerine bir adet üçlü tandem pompa kullanılması uygun görülmüştür. Tandem pompanın üç bölümü birbiri ile bağlantılı olup, tek bir bölümünün çalışmasıyla bütün bölümleri aynı anda çalışmaktadır.

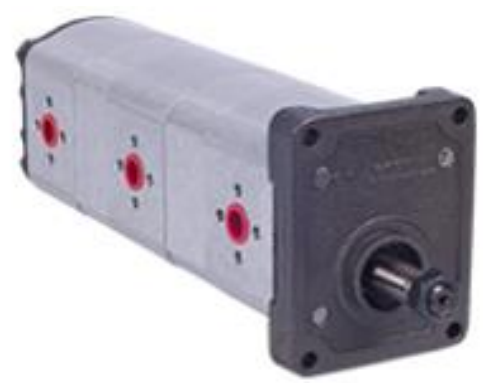

Şekil 13. Üçlü tandem dişli pompa [10]

\section{4. Çapa makinası seçimi}

Hesaplanan pompa debisine uygun olan çapa makinasının seçimi için öncelikle motor gücünün hesaplanması gerekir. Bunun için şu formül kullanılmaktadır:

$$
P=\frac{\mathbf{p} * \mathbf{Q}}{540}
$$

Burada P motor gücü (kW), p pompa basıncı (bar) ve $Q$ pompa debisidir (lt/dak).

Denklem 7'de p değeri 150 bar, Q değeri 13.56 lt/dak ve motor verimi 0.9 alındığında;

$$
P=\frac{150 * 13,56}{540}
$$

motor gücü, $\mathrm{P}=3.76 \mathrm{~kW}$ bulunur. Dolayısıyla seçilen üçlü tandem dişli pompanın tek bir bölümünün minimum güç gereksinimi $3.76 \mathrm{~kW}$ 'dır. Üçlü tandem dişli pompanın bütünü için gerekli olan minimum güç $3.76 \times 3=11.28 \mathrm{~kW}$ yani 15 BG olacaktır. Araçta bulunan hidromotorların ve hidrolik pistonun ayrı ayrı güç gereksinimleri göz önünde bulundurulduğunda araçtaki tüm bölümleri aynı anda çalıştırmak için minimum 15 BG' lik çapa makinası kullanılması gerekmektedir. Araçta kullanılmak üzere seçilen çapa makinasının teknik özellikleri Tablo 12'de verilmektedir.

\begin{tabular}{ll} 
Tablo 12. Çapa makinasının teknik özellikleri [11] \\
\hline Güç & $22 \mathrm{HP}(16,5 \mathrm{~kW})$ \\
Silindir hacmi & $510 \mathrm{cc}$ \\
Devir sayısı & $3000 \mathrm{dev} / \mathrm{dak}$ \\
Debriyaj & Kuru konik kavramalı \\
Şanzıman & 3 ileri 1 geri vites, kol ile \\
Ağırlık & kumandalı \\
Tekerlek & $1422 \mathrm{~N}(145 \mathrm{~kg})$ \\
grubu & $6,50 \times 80-12$ (opsiyonel) \\
\hline
\end{tabular}

Çapa makinasında 2 adet kuyruk mili bulunmaktadır. Bunlardan birisi vitesten bağımsız motor mili şanzıman miliyle aynı dönme hızına sahiptir. Diğeri ise vitesle beraber çalışan kuyruk mili vites değiștirme hızına bağlıdır. Tablo 13'de motor devri $3000 \mathrm{dev} /$ dak 'da iken vites durumuna göre kuyruk millerinin devir sayıları verilmektedir. 
Tablo 13. Maksimum motor devrinde (3000 dev/dak) kuyruk mili devirleri [11]

\begin{tabular}{cccc}
\hline & 1.Vites & 2. Vites & 3.Vites \\
\hline $\begin{array}{c}\text { Motor mili } \\
\text { (dev/dak) }\end{array}$ & 3000 & 3000 & 3000 \\
$\begin{array}{c}\text { Vites mili } \\
\text { (dev/dak) }\end{array}$ & 900 & 300 & 210 \\
$\begin{array}{c}\text { Yol mili } \\
\text { (dev/dak) }\end{array}$ & 105 & 35 & 25 \\
$\begin{array}{c}\text { Geri vites } \\
(\text { dev/dak) }\end{array}$ & 95 & & \\
\hline
\end{tabular}

Aracın düz, eğimli ve çamurlu zeminde çalışma durumlarına göre çapa makinası ve römork için traktör desenli tekerlekler seçilmiştir.

\subsection{Araç şasesinin gerilme analizi}

Tasarlanan aracın şasesinin üzerindeki yükleri emniyetle taşıyıp taşıyamayacağını ve kullanılan metal profil kesit ölçülerinin mukavemet açısından yeterli olup olmadığını belirlemek amacıyla ANSYS Workbench programı ile gerilme analizi yapılmıştır.

Aracın römork bölümünün maksimum hacmi 0,67 m3, minimum hacmi 0,39 m3، dür. Römork bölümünün maksimum hacimde alabileceği maksimum yük $702 \mathrm{~kg}$ iken minimum hacimde alabileceği maksimum yük 396 kg' dır. Şase malzemesi olarak St37-2 yapı çeliği (akma mukavemet değeri $235 \mathrm{MPa}$, çekme mukavemet değeri $340 \mathrm{MPa}$ ) seçilmiştir. Römork bölümünün 70 cm' lik kısmı 50mmx50mmx2mm kesit ölçüleri olan kare profilden, römorkun diğer bölümleri ise römork hacmini genişletebilmek için 40x40x2 mm kesit ölçüleri olan kare profilinden imal edilmiştir. En düșük hacimde $40 \mathrm{mmx} 40 \mathrm{mmx} 2 \mathrm{~mm}$ kesit ölçüsüne sahip profiller $50 \mathrm{mmx} 50 \mathrm{mmx} 2 \mathrm{~mm}$ kesit ölçülü kare profilin içinde durmaktadır. Römork bölümünün kapakları $1 \mathrm{~mm}$ kalınlığındaki st37 sac malzemeden imal edilmiştir.

Sonlu elemanlar modeli, 7844 eleman ve 15085 düğümden oluşturulmuştur. Araç şase modeli tekerlerin oturacağı bölümlerden mesnetlenmiştir. Şase üzerine 10 kN' luk yayılı yük uygulanmıştır.

Analiz sonucunda maksimum Von Mises gerilmesinin $103 \mathrm{MPa}$ olduğu ve motor bölümünde (çapa makinası tarafında) arka tekerlerin bağlandığı bölgede meydana geldiği görülmüştür (Şekil 14). Buna rağmen meydana gelen maksimum VonMises gerilmesi seçilen malzemenin akma mukavemet değerinden yaklaşı $\% 60$ oranında düşük olduğundan şasenin maksimum yüklemeye karşı emniyetli olduğu sonucuna varılmıștır.

\subsection{Hidrolik sistem}

Araç bölümlerinin montaj işlemi tamamlandıktan sonra aracın römork ve yükleme bölümlerinin hidrolik sistem bağlantıları yapılmıştır. Şekil 15 ve Şekil 16 sırasıyla araç yüksüz çalışırken (konveyör bant, hidrolik piston ve toplama bölümü devre dışı) ve tam yükte çalıșırken (konveyör bant, hidrolik piston ve toplama bölümü devrede) hidrolik devre şemalarını gösterilmektedir.

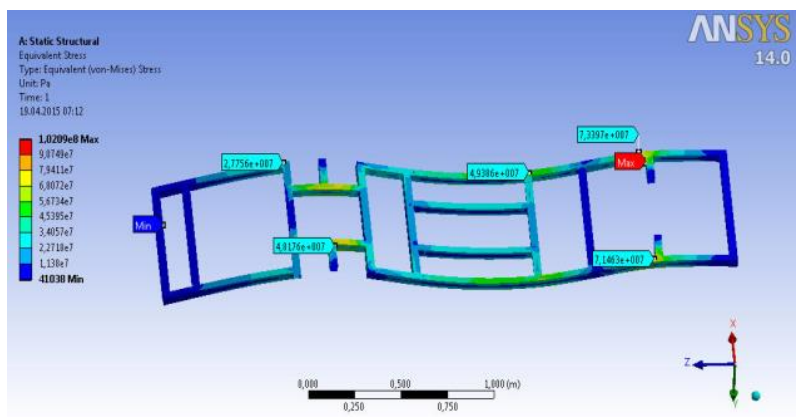

Şekil 14. Araç şasesi VonMises gerilme dağılımı

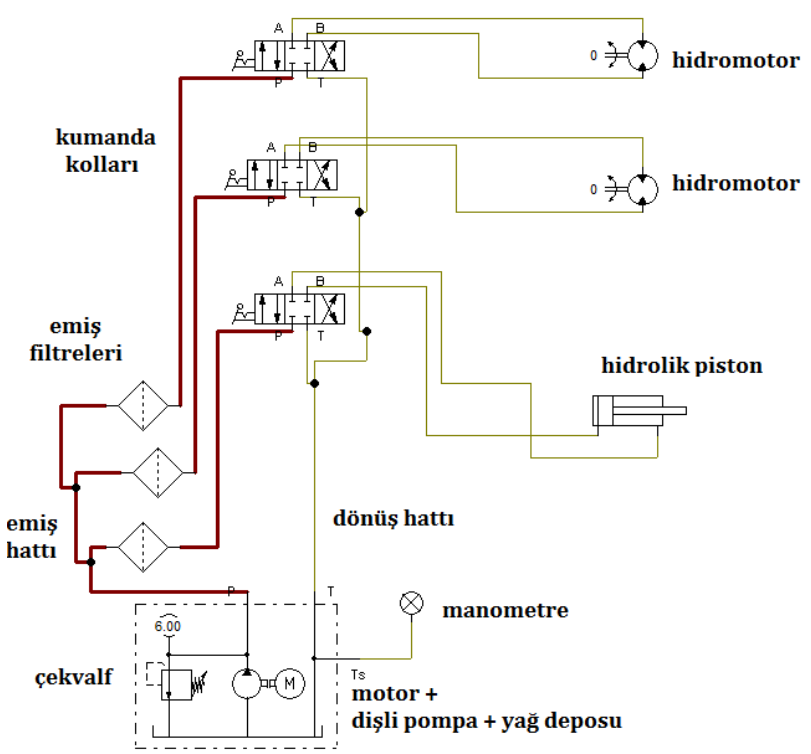

Şekil 15. Araç yüksüz çalışırken hidrolik devre şeması

Araç yüksüz halde çalışırken, yani yükleme bölümü, toplama bölümü ve hidrolik piston devre dişı iken, hidrolik devre șu șekilde çalıșmaktadır: Capa makinası prizdirek kuyruk miline elastik kaplinle bağlanan dişli pompanın tahrik edilmesiyle yağ deposundan yağ emilerek basınçlı halde yağ kumanda kollarına ulaşır. Kumanda kollarına gelen yağ hidromotorlara veya hidrolik pistona yönlendirilmemişse geri dönüş hattı üzerinden yă deposuna geri döner (Şekil 15).

Araç yüklü halde çalışırken, yani yükleme bölümü ve toplama bölümü hidromotorları devrede iken, hidrolik devre şu şekilde çalışmaktadır: Dişli pompanın tahrik edilmesiyle yağ deposundan yă emilerek basınçlı halde yağ kumanda kollarına ulaşır. Kumanda kollarına gelen yağ hidrolik hortumlarla hidromotorlara ulaştırılır. Basınçlı yağ hidromotorları çalıştırdıktan sonra geri dönüş hattından yağ deposuna geri döner. Kumanda kolları yönlendirmeyi kapatmadı̆̆ı müddetçe yağın döngüsü 
devam eder (Şekil 16). Sistemdeki hidrolik piston için de aynı çalışma şekli söz konusudur.

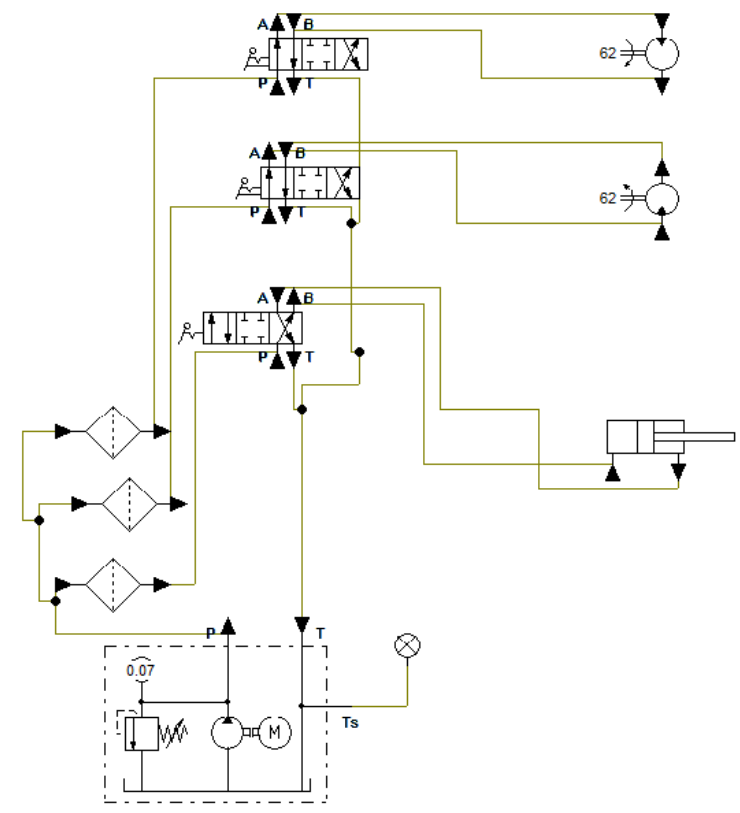

Şekil 16. Araç yükte çalıșırken hidrolik devre șeması

\section{Bulgular}

Katı atık toplama aracına ait bileșenlerin ișçilik maliyeti hariç yaklaşık maliyetleri ve aracın yaklaşık toplam maliyeti Tablo 14'de verilmektedir. Katı atık toplama aracının çapa makinası hariç ağırlığı yaklaşık $150 \mathrm{~kg}$ olmuştur.

Tablo 14. Katı atık toplama aracı bileşenlerinin yaklaşık maliyetleri (iş̧̧ilik hariç)

\begin{tabular}{ll}
\hline Araç / Parça /Malzeme & Maliyet (TL) \\
\hline Çapa makinası (1 adet) & $11.000-13.000$ \\
Tandem dişli pompa (3'lü, 1 & $1.200-1.500$ \\
adet) & $650-800$ \\
Hidromotor (2 adet) & $350-500$ \\
Hidrolik piston (1 adet) & $450-750$ \\
Konveyör bant (2.5 m) & $700-950$ \\
Hidrolik hortum & $800-950$ \\
Hidrolik ekipman & $700-850$ \\
Metalik malzeme (profil, sac & \\
vb.) & $400-550$ \\
Hidrolik yağ (M46, 4x18 lt) & $250-350$ \\
Teker (4 adet) & $75-100$ \\
Yataklı Rulman (6 adet) & $16.575-20.300$ \\
Toplam Maliyet (TL)
\end{tabular}

Katı atık toplama aracının montaj işlemlerinden sonra arazide test etmek için gerekenden daha düşük güce sahip (5 BG) çapa makinası kullanılmış ve araç hareket ettirilerek test edilmiştir (Şekil 17).

5 BG' ne sahip çapa makinası araçtaki sistemleri çalıştıracak yeterli güce sahip olmadığından ve uygun çapa makinası maddi nedenlerle tedarik edilemediğinden test aşamasında çapa makinası yerine gereken gücü sağlayan traktör (48 BG) kullanılmıştır (Şekil 18).

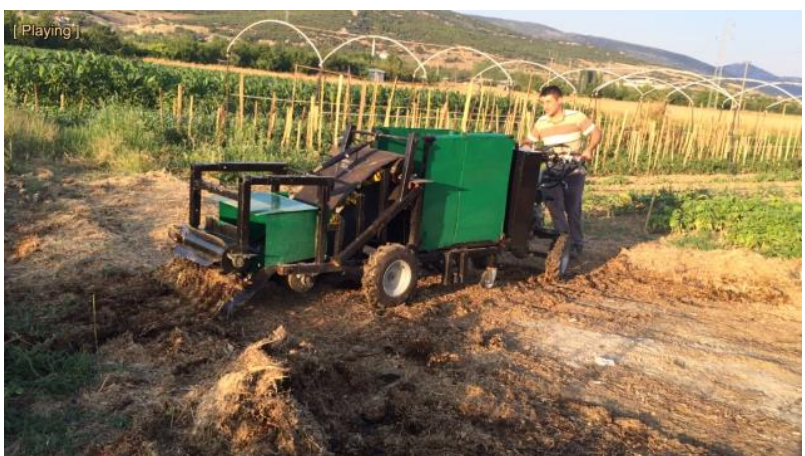

Şekil 17. Aracın çapa makinası ile arazide test edilmesi

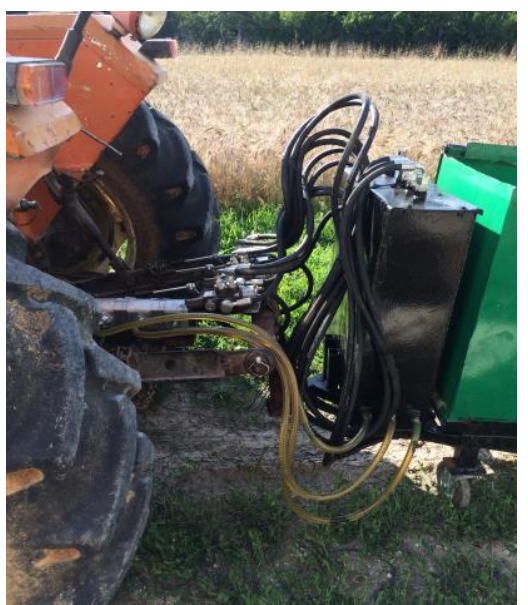

Şekil 18. Traktöre monte edilmiş katı atık toplama aracı

Aracın traktörle yapılan denemelerinde ilk olarak aracın yükleme bölümünde bulunan kazıyıcı aktif halde çalıştırılarak kontrol edilmiştir. Daha sonra konveyör bant bölümü denenmiș ve konveyör bantın gergi tamburundan kayarak sistemi durdurduğu gözlemlenmiştir. Gergi tamburu çevresine ek parçalar kaynak yapılarak rijitliği artırılmış ve konveyör bant sistemi tekrar denenmiștir. Konveyör bant sisteminin sorunsuz halde çalıștığı gözlemlenmiștir. Sonra konveyör bant ve kazıyıcı bölümleri aynı anda çalıştırılarak test edilmiş ve birlikte sorunsuz çalıştıkları gözlemlenmiştir (Şekil 19).

Son olarak römork bölümü denenmiş ve deneme sırasında hidrolik pistonun araç gövdesine bağlı bulunduğu milin yerinden çıktığı görülmüştür. Mil gerekli kaynak ișlemleriyle gövdeye monte edilmiș ve römork bölümü tekrar denenmiștir. Römorkun istenilen eğim açısında sorunsuz çalıștığı gözlemlenmiştir (Şekil 20).

Farklı uygulama alanlarında denenen aracın yükleme bölümündeki kazıyıcı (toplayıcı) kısmı, kürüme küreğinin sıyırdığı katı atıkları konveyör bant üzerine aktarmakta ve konveyör bantta üzerine aktarılan katı atıkları römorka aktarmaktadır.

Aracın arazide yapılan testlerinde iki farklı katı atık kullanılmıştır: hafif atık ve ağır atık. Hafif atık olarak, kurumuş silaj atığı, saman gibi atıklar değerlendirilmiştir. Ağır attk olarak ise hayvansal atık, kum, toprak gibi atıklar değerlendirilmiștir. 
Şekil 21'de araç hafif atıkla, Şekil 22'de araç ağır atıkla denenirken çekilmiş resimler verilmektedir.

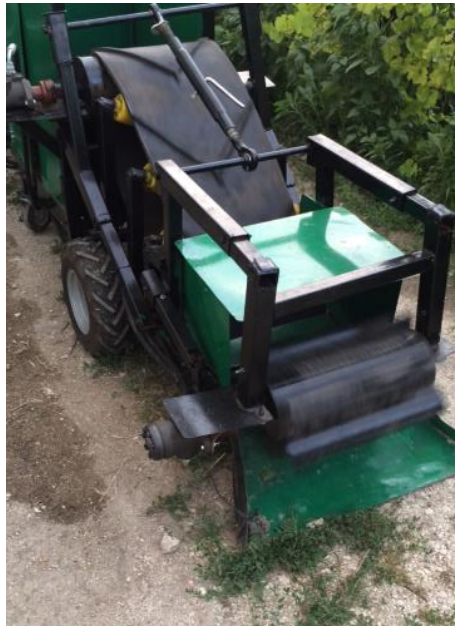

Şekil 19. Aracın konveyör bant ve kazıyıcı sistemlerinin test edilmesi

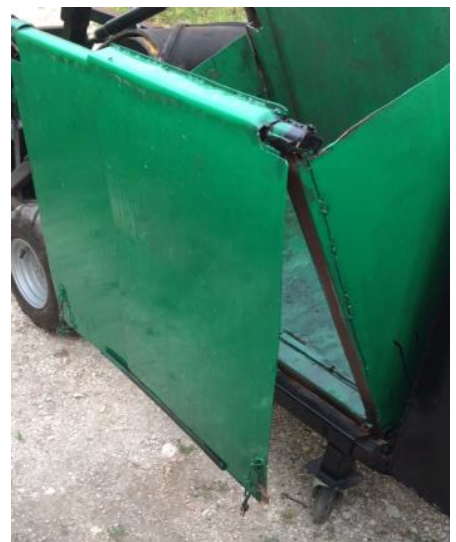

Şekil 20. Römorkun test edilmesi

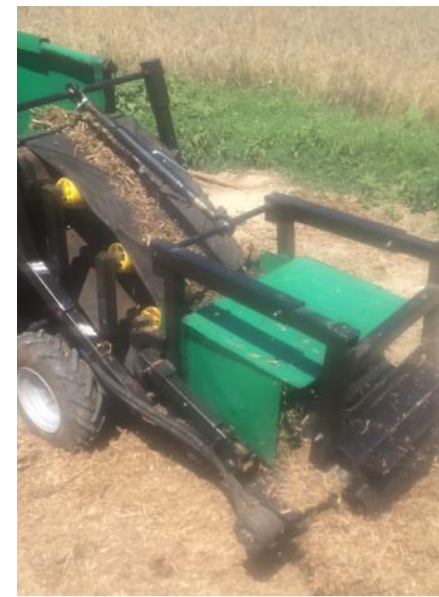

Şekil 21. Aracın hafif atıkla test edilmesi

Arazi testlerinde atıkla doldurulmuș olan römorkun boşaltma işlemleri Şekil 23' de gösterilmektedir.

Aracın arazide hafif ve katı atıklarla gerçekleştirilen testlerinden elde edilen rakamsal sonuçlar Tablo 15 'de verilmektedir.

Aracın yapılan testlerinde hafif atıkların ağır atıklara göre daha kısa sürede toplanıp römork bölümüne aktarıldığı görülmüştür. Römorka yüklenen hafif atıklar değiștirilebilen römork hacmine bağlı olarak $200 \mathrm{~kg}$ ile $350 \mathrm{~kg}$ arasında değișkenlik göstermektedir. Römorka yüklenen ağır atıklar ise değiștirilebilen römork hacmine bağlı olarak $400 \mathrm{~kg}$ ile $550 \mathrm{~kg}$ arasında değişkenlik göstermektedir. Her iki atık türü için römork doldurma kapasitesi ve ağır katı atık için römork doldurma süresi açısından hedef kriterden bir miktar sapma söz konusudur.

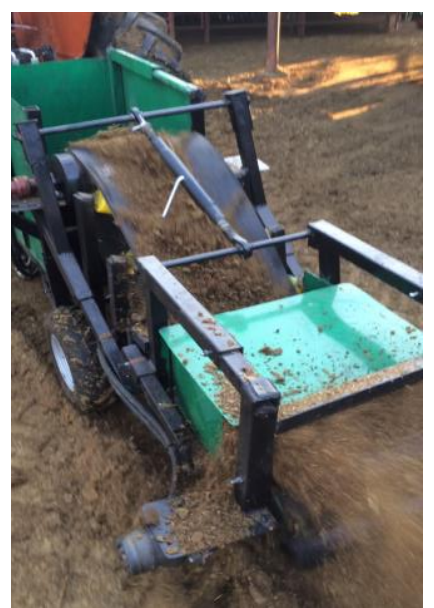

Şekil 22. Aracın ağır atıkla test edilmesi

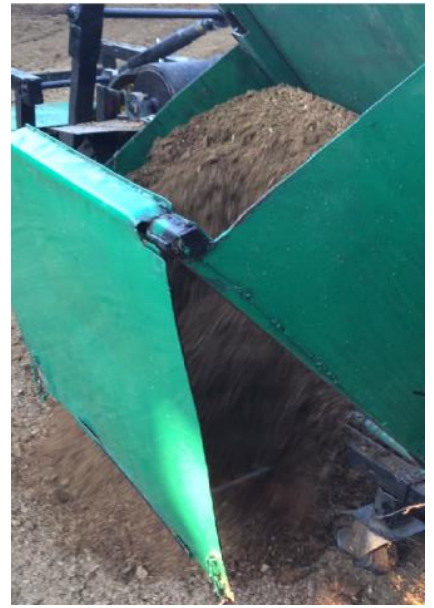

Şekil 23. Atıkla dolu römorkun boşaltılması

\section{Tartışma ve Sonuç}

Katı atık toplama aracının tasarımı aşamasında yükleme bölümünde konveyör bant ya da elevatörlü sistem şeçenekleri düşünülmüş olup römorkun dengeli şekilde ve hızlı doldurulması amacıyla konveyör bant sistemi seçilmiştir. Konveyör bant sisteminde mesafe kısa olmasına rağmen tamburlar haricinde bant $45^{\circ}$ eğimde çalışacağı için belli aralıklarla rulo ile desteklenmiştir. Yükleme bölümünde eğimden dolayı biriken katı atıkları konveyör bant sistemi üzerine aktarmak için pistonlu çektirme sistemi düşünülmüş fakat kullanımının pratik olmayacağı düşünülerek kanatlı kazıyıcı sistemi tasarlanmıştır. 
Tablo 15. Aracın arazi test sonuçları

\begin{tabular}{lcccccc}
\hline \multirow{2}{*}{ Özellik } & \multicolumn{2}{c}{ Hafif Katı Atık } & & \multicolumn{2}{c}{ Ağır Katı Atık } \\
& Hedef Kriter & $\begin{array}{c}\text { Uygulama } \\
\text { Sonucu }\end{array}$ & & Hedef Kriter & $\begin{array}{c}\text { Uygulama } \\
\text { Sonucu }\end{array}$ \\
\cline { 1 - 3 } \cline { 5 - 6 } Atık toplama alanı $\left(\mathrm{m}^{2}\right)$ & $150-250$ & 200 & & $150-250$ & 150 \\
Konveyör bant yükleme hızı (m/sn) & 1 & 1 & & 1 & 0,5 \\
Konveyör bant kapasitesi (kg/dk) & $70-150$ & 70 & & $70-150$ & 100 \\
Konveyör bant yükleme yüksekliği (cm) & $65-80$ & 80 & & $65-80$ & 80 \\
Römorka kapasitesi (kg) & 700 & & 350 & & 700 & 550 \\
Römork doldurma süresi(dk) & $7-10$ & 8 & & $7-10$ & 15 \\
Römork boșaltma süresi (dk) & $0,5-1$ & 0,5 & & $0,5-1$ & 1 \\
\hline
\end{tabular}

Katı atıkların konveyör bant sistemine aktarılmasını sağlayan kazıyıcı sistemin ileri-geri ve yukarı-aşağı hareketlerinin biribiri içine geçen profiller yerine pistonlu sistemle daha pratik ve kolay bir şekilde yapılabileceği düşünülmektedir. Kazıyıcı bölümün konveyör banttan mesafeli olmasından dolayı toplanan katı atıkların tamamının bant üzerine aktarılamadığı görülmüştür. Kazıyıcının banta yaklaştırılması ve kazıyıcı kanatlarının düz yapılmasıyla daha çok katı atığın bant üzerine aktarlabileceği değerlendirilmektedir. Kazıyıcı üstündeki kapalı bölümün kazıyıcıya yaklaştırılmasının da bant üzerine aktarılacak atık miktarını artırabileceği düşünülmektedir.

Aracın tasarımında römork bölümünün hacmi birbiri içine geçen profillerle çalışma ortamına göre arttırılıp azaltılacak şekilde tasarlanmıştır. Biribiri içine geçen profiller yerine pistonlu sistemle daha pratik ve kolay bir şekilde hacmin artırılıp azaltılabileceği düşünülmektedir. Römork bölümüne ait hidrolik pistonun ilk olarak römorkun yan tarafına monte edilmesi düşünülmüș fakat piston bağlantısında yaşanacak mukavemet yetersizliği nedeniyle piston römorkun alt bölümüne monte edilmiștir.

Araçtaki tüm sistemler için ayrı ayrı dişli pompa seçilerek üçlü tandem pompa sisteme monte edilmiştir. Üçlü tandem pompa yerine tek bir dişli pompa seçilip tüm sistem için kullanılacak olması durumunda sistemdeki hidromotorlara giden tüm hidrolik hortumların çaplarının değiştirilmesi gerekecektir. Ayrıca sistemde tek bir dișli pompanın kullanılması kumanda kolları, yağ tankı, dişli pompa ve hidromotorlar arasındaki montaj işlemini nispeten zorlaştıracaktır. Buna rağmen toplama ve yükleme bölümlerindeki hidromotorlarla römork yükünü boşaltma amacıyla kullanılan hidrolik pistonun aynı anda çalıştırılmayacakları değerlendirildiğinde üçlü tandem pompa yerine ikili tandem pompa kullanılabilir. Bu durumda gerekli olan 22 BG 'lük çapa makinası yerine 12 BG'lük çapa makinası yeterli olacaktır. Bu da hidrolik devre şemasında değişikliğe gidilmesini gerektirecektir.

Aracın 150 - $250 \mathrm{~m}^{2}$ alanda yapılan testlerinde, 7 ile $15 \mathrm{dk}$ arasında değișen bir zamanda katı atıkları topladığı ve katı atıkların toplanıp yüklenmesinde kolaylık sağlandığı görülmüştür. Aracın uygulama alanı, toplama süresi ve boșaltma süreleri göz önünde bulundurulduğunda $150-250 \mathrm{~m}^{2}$ gibi alanlara sahip küçük ve nispeten küçük alanlı orta ölçekli besihanelerde rahatlıkla kullanılabileceği sonucuna varılmıştır. Aracın $500 \mathrm{~m}^{2}$ ' lik bir alanda yapılacak uygulamasında ise, 30 ile $40 \mathrm{dk}$ arasında bir sürede katı atıkları toplayıp boşaltması öngörülmektedir.

$\mathrm{Bu}$ çalışma ile ilgili aşağıda verilen sınırlamalar bulunmaktadır:

Araç şasesinin sonlu elemanlar analizinde;

1. aracın gövde montajında kaynak bağlantılarının eksiksiz yapıldığı kabul edilmiştir,

2. mesnetlemeler tekerlerin gövdeye bağlı olduğu noktalardan yapılmıștır,

3. gerilme analizi statik yükleme şartlarında gerçekleștirilmiştir.

Aracin uygulama testlerinde;

1. kullanılan hafif veya ağır olarak nitelendirilen atıkların kategorisine göre eşit özellikte oldukları kabul edilmiştir,

2. atıkların içerisinde büyük çaplı taş, sıvı halde atık veya yoğunluğu artmış tezek olmadığı varsayılmıștır.

Yukarıda listelenen sınırlamalara göre, araç sınırlı katı atıklarla ve sınırlı çalışma alanına sahip olmakla birlikte araç bölümlerinde yapılacak tasarım değişiklikleri ile farklı alanlarda farklı amaçlar için kullanılabilecektir.

\section{Teşekkür}

5038-YL1-17 No`lu proje ile çalıșmamı maddi olarak destekleyen Süleyman Demirel Üniversitesi Bilimsel Araştırma Projeleri Yönetim Birimi Başkanlığı'na teşekkür ederim.

\section{Kaynakça}

[1] Almix Makina İmalat İnşaat. Nak. San. Tic. Ltd. Ști, 2018. Gübre Yönetimi. http://www.almix.com.tr/Urunler.aspx?KatI D=11 (Erişim Tarihi: 25.07.2018).

[2] Anıl Yatağanlı Tarım Makinaları, 2018. Ürünlerimiz. http://www.aniltarim.com/tr/ urunlerimiz/ (Erişim Tarihi: 25.07.2018). 
[3] Anonim, 2019. Sı̆̆ır Hastalıkları. http://www.tarimkutuphanesi.com/sigir_ha staliklari_00145.html___Erișim_ Tarihi: 26.09.2019).

[4] Ay, S., Evcik, D. 2008. Kronik Bel Ağrılı Hastalarda Depresyon ve Yaşam Kalitesi. Yeni Tıp Dergisi, 25: 228-231.

[5] Karyer-Tatmak, 2019. Asfalt Kazıma Makinaları. https://karyer-tatmak.com/ category/bomag/page/4/ (Erişim Tarihi: 26.09.2019).

[6] Ziraat Tarım Market, 2018. Çelikel Balya Yükleme Makinası. https://www.ziraattarim market.com/urun/celikel-balya-yuklememakinasi.html (Erişim Tarihi: 09.12.2018).

[7] Tutkun Kardeşler, 2019. Taş Toplama Makinası. http://www.tutkunkardesler.com/ urunler.html (Erişim Tarihi: 26.09.2019).
[8] Pugh, S. 1991. Total Design: Integrated Methods for Successful Product Engineering, Addison-Wesley Publishing Company, Boston, 278s.

[9] Yılmaz Redüktör, 2017. Konveyörler. https://www.yr.com.tr/?Page= AppConveyors (Erişim Tarihi: 18.12.2017).

[10] Türk Sanayi Market, 2017. Dişli Pompalar. https://www.turksanayimarket.com/hidroli k-tr/pompalar-tr/dili-pompalar/ (Erişim Tarihi: 12.12.2017).

[11] Yağmur Tarım Makinaları, 2019. Çapa Makinalarl. https://www.yagmur.com/ urunler/capa-makineleri/ (Erişim Tarihi: 09.10.2019). 